\title{
Direct Marking Device Identifier
}

National Cancer Institute

\section{Source}

National Cancer Institute. Direct Marking Device Identifier. NCI Thesaurus. Code C101678.

An identifier that is marked directly on a device. 